\title{
Scanning Electron Microscopy Study of the Dorsal Surface of the Tongue in Zaedyus pichiy (Mammalia, Xenarthra, Dasypodidae)
}

\author{
Estudio al Microscopio Electrónico de Barrido de la Superficie Dorsal \\ de la Lengua de Zaedyus pichiy (Mammalia, Xenarthra, Dasypodidae)
}

Ciuccio, M.*; Estecondo, S. ** \& Casanave, E. B. ${ }^{* * *}$

CIUCCIO, M.; ESTECONDO, S. \& CASANAVE, E. B. Scanning electron microscopy study of the dorsal surface of the tongue in Zaedyus pichiy (Mammalia, Xenarthra, Dasypodidae). Int. J. Morphol., 26(1):13-18, 2008.

SUMMARY: The dorsal surface of the tongue of Zaedyus pichiy (Desmarest, 1804) was examined by scanning electron microscopy. Conical and branched filiform, fungiform and vallate papillae are described. No foliate papillae were seen. Conical filiform papillae are distributed in the apex, both lateral edges and caudally to the vallated ones. The branched papillae represent the most numerous type of lingual papillae; they are distributed over the entire dorsal surface of the tongue. The fungiform papillae are placed among the filiform ones, more densely distributed on the tip of the lingual apex. In the posterior third of the tongue there are two vallated papillae surrounded by a deep circular grove. Fungiform and circumvallate papillae are related to the sense of taste; openings of taste pores are visible on their surface. The filiform papillae have a mechanical and protective role.

KEY WORDS: Mammals; Xenarthra; Dasypodidae; Armadillo; Tongue; Lingual Papillae; SEM.

\section{INTRODUCTION}

Zaedyus pichiy (pichi) is a native armadillo that inhabits in grasslands, open pampas and arid regions of southern South America, in central and southern Argentina and Chile, to the Strait of Magellan (Texera, 1973, Gardner, 2005). Its diet consists of insects, worms, small vertebrates, some vegetable materials and carrion; local people use it as pet and food source (Parera, 2002; personal observations). The pichi is still abundant and widely distributed in its natural environment, and in Argentina it is categorized as a low risk species (Díaz \& Ojeda, 2000). Little is known about its morphology (Estecondo et al., 1996, 2005; Squarcia \& Casanave, 1999; Galíndez et al., 2003; Casanave \& Galíndez, in press) and the structure of the dorsal surface of the tongue has not been studied.

In mammals, four different types of tongue papillae (fungiform, circumvallate, foliate and filiform) can be found on the dorsal surface (Emura et al., 2006), but the structure of the tongue reveal a variability of morphological features related to the type of food, habit, and taxonomy (Jackowiak \& Godinicki, 2005; Okada \& Schraufnagel, 2005). From a comparative point of view, this variability is significant between high systematic units, such as orders or families, although frequently there are also interspecies differences (Iwasaki, 2002; Kobayashi et al., 2005; Emura et al., 2001, 2006; Jackowiak \& Godynicki, 2004, 2005).

There are many SEM studies of lingual papillae in mammals (Jackowiak, 2006; Kulawik \& Godynicki, 2007) and, in armadillos, Euphractus sexcinctus (Morais \& Watanabe, 1988), Dasypus novemcinctus (Morais et al., 1991, 1994), Chaetophractus vellerosus (Estecondo et al., 2001) and Chaetophractus villosus (Estecondo et al., 2004) were investigated.

\footnotetext{
"Laboratorio de Fisiología Animal, Departamento de Biología, Bioquímica y Farmacia (DBByF), Universidad Nacional del Sur (UNS), San Juan 670, 8000 Bahía Blanca, Argentina. Scholarship, CONICET. E-mail: mciuccio@uns.edu.ar.

** Lab. de Histología Animal, DBByF, UNS, San Juan 670, 8000 Bahía Blanca, Argentina. E-mail: silviest@ criba.edu.ar.

${ }^{* * * *}$ Lab. de Fisiología Animal, DBByF, UNS, San Juan 670, 8000 Bahía Blanca, Argentina. Researcher, Consejo Nacional de Investigaciones Científicas y Técnicas (CONICET).

This study was funded by SGCyT (UNS), Project 24/B122, and by ANPCyT, PICTR 074/03.
} 
The aim of this work is to study with SEM the dorsal surface of the tongue in the armadillo Z. pichiy, and to describe the form, characteristics and distribution pattern of the different types of papillae there present.

\section{MATERIAL AND METHOD}

The tongues of three mature Z. pichiy of both sexes captured around Bahía Blanca city (Buenos Aires province, Argentina), were used. The whole tongues were fixed in modified Karnovsky solution, containing $2.5 \%$ glutaraldehyde and $2 \%$ paraformaldehyde in $0.1 \mathrm{M}$ sodium cacodylate buffer ( $\mathrm{pH} 7.4$ ), for three days, at $4{ }^{\circ} \mathrm{C}$; small samples (approximately $2 \mathrm{~mm}^{2}$ ) of tissue, dissected from some areas (from the tip to the base) of the dorsal tongues were obtained.

They were washed in $0.1 \mathrm{M}$ sodium cacodylate buffer ( $\mathrm{pH}$ 7.4) and treated with $8 \mathrm{~N}$ hydrochloric acid, at 60 ${ }^{\circ} \mathrm{C}$, for $1 \mathrm{~h}$, to remove any extracellular mucous substance from the lingual surface (Estecondo et al., 2001). The dehydration was made in increasing series of acetone, critical point dried in Polaron apparatus E-3000 and coated with gold in Ion Sputter model 3 Pelco 91000. The samples were examined and photographed with an Evo 40 XVP scanning microscope (Cambridge, England) at 5-7 kV.

\section{RESULTS}

Macroscopically, the tongue of Z. pichiy has a triangular shape elongated in anteroposterior direction, with a sharp apex. Scanning electron microscopy shows three kinds of papillae: filiform, fungiform and vallate. No foliate papillae were found.

The most numerous papillae are the filiform ones, covering the apex and body of the tongue. They are simple (conical) or branched, divided into one main and two to four pointed accessory processes, curved principally towards the pharynx (Fig. 1). The conical ones are located on the tip, where they are prominent in size (Fig. 2), on both lateral edges and in the posterior third of the tongue, behind vallate papillae, where they are small and less numerous. Filiform branched papillae lie in rows and are compactly distributed over the entire dorsal surface (Fig. 3 ), decreasing in number throughout the posterior third. They have two accessory processes from the apex to the anterior third (Fig. 1) and two to four at the posterior twothirds (Fig. 4). The length and number of the accessory processes vary throughout the surface of the tongue. In the posterior third, the length of processes decreases.

Fungiform papillae are dome-shaped and wider in diameter than filiform ones. They are surrounded by a continuous furrow (Fig. 3). Taste pores are distributed on the top of these papillae between squamous epithelia (Fig. 5 ). On the apex of the tongue the fungiform papillae form clusters of two or three papillae (Fig. 1), in the middle and posterior part of the tongue they are regularly scattered between filiform papillae (Fig. 3).

On the root of the tongue two oval and elongated vallate papillae are founded, they are situated symmetrically and obliquely to the median line of the tongue. The body of these papillae is delimited by a deep circular grove and this area is surrounded by filiform papillae (Fig. 6). Each one shows visible taste pores on their convex surface (Fig. 6). At high magnification, on the interpapilar areas and places without any papillae, a network of microridges can be observed.

\section{DISCUSSION}

The presence of three types of papillae, filiform, fungiform and circumvallate, in the surface tongue of $Z$. pichiy, as revealed by the scanning electron microscopic observations, is a morphological pattern basically similar to the one described for other armadillo's species (Morais \& Watanabe, 1988; Morais et al., 1991; Estecondo et al., 2001; Estecondo et al., 2004).

The morphology of filiform papillae is also comparable to that reported for Chaetophractus vellerosus and C. villosus (Estecondo et al., 2001, Estecondo et al., 2004), although some interspecific differences in the size and in the number of branches were found.

Despite these three species are principally classified as omnivorous (Parera), those variations may be due to mastication methods and/or dietary habits, as has been claimed for other mammals (Yoshimura et al., 2002).

The pattern of filiform papillae covering the entire dorsal surface of the tongue, with the number of branches increasing to the middle third of the organ, seems to be common in armadillos and it was also observed in Euphractus sexcinctus (Morais \& Watanabe, 1988), Dasypus novemcinctus (Morais et al., 1994), C. vellerosus (Estecondo et al., 2001) and C. villosus (Estecondo et al., 2004). The absence of taste pores suggests that filiform 

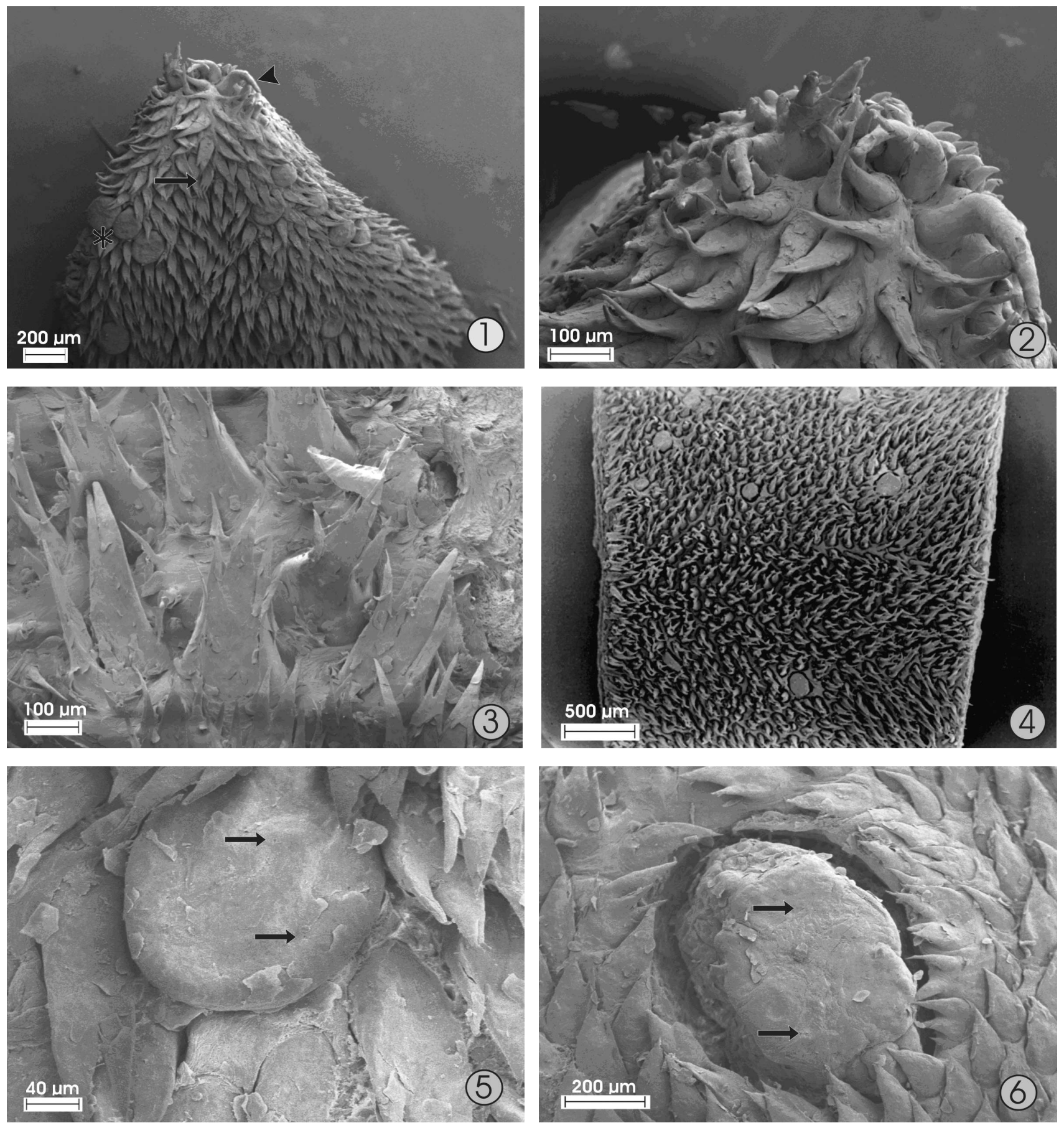

Fig. 1. SEM of lingual apex of Zaedyus pichiy tongue showing fungiform (*), simple conical $(\rightarrow)$ and branched $(\rightarrow)$ filiform papillae. 106X. Fig. 2. Prominent simple conical filiform papillae of the tongue apex. 300X.

Fig. 3. Medial third of the tongue: branched filiform and fungiform papillae surrounded by a deep groove. 30X.

Fig. 4. Posterior third of the tongue: filiform papillae with several branches. $250 \mathrm{X}$.

Fig. 5. Fungiform papillae rounded by a deep grove with deciduous epithelium and openings of taste buds $(\rightarrow)$. $657 \mathrm{X}$.

Fig. 6. Vallate papillae with openings of taste buds $(\rightarrow)$, surrounded by several filiform papillae. 200X.

papillae have only mechanical function during the mastication process, while its abundance and distribution suggest their participation in the protection of the dorsal surface, as in other mammal species (Emura et al., 2001; Ünsal et al., 2003). The fact that filiform papillae are easily bent in the direction of the radix but not in the opposite 
direction, could be related with the need to secure in place and move the food taken into the mouth (Iwasaki; Jackowiak, 2006). According to Iwasaki, the characteristics of the lingual papillae, in particular those of the filiform ones, might reflect phylogeny, been similarities among filiform papillae especially clear within the same order, and differences mainly evident between different orders of mammals.

The morphology and distribution of fungiform papillae observed in Z. pichiy is typical for the studied species belonging to Dasypodidae (Morais \& Watanabe, 1988; Morais et al., 1991; 1994; Watanabe et al., 1992; Estecondo et al., 2001, 2004). Those species, with subterranean habits, are distinguished by the reduction of sight and a strongly developed sense of smell (García Samartino et al., 1987). According to Jackowiak (2006), it may be expected that the sense of taste should play a significant role in animals with this style of life.

The array of gustatory fungiform papillae in clusters on the apex of the tongue was also observed in C. vellerosus (Estecondo et al., 2001) and C. villosus (Estecondo et al., 2004) and in other mammals, as rodents and carnivores (Emura et al., 2001; Jackowiak \& Godynicki, 2004). The function of this special system of papillae is probably related with the preliminary analysis and tasting of food (Jackowiak \& Godynicki, 2004).

As in other species of mammals (Jackowiak, 2006), the distribution of filliform papillae surrounding the fungiform ones, suggests a protective role.

The presence in Z. pichiy of only one pair of circumvallated papillae located on the root of the tongue, coincides with the observed in all previously studied armadillos (Cuba Caparo, 1979; Morais \& Watanabe; Watanabe et al.; Morais et al., 1994; Estecondo et al., 2001, 2004), as well as in some other mammals as opossum (Martinez et al., 1998), chinchilla (Martinez et al., 2000), pig (Kumar \& Bate, 2004), rabbit (Kulawik \& Godynicki) and horse (Kobayashi et al.).

The presence of taste pores in fungiform and circumvallated papillae clearly suggests that they are gustatory papillae, as shown in other species (Ünsal et al.).

Is well known that the presence of foliate papillae has been considered a primitive characteristic (Kobayashi et al.); a remarkable fact is that in spite of been Xenarthra a primitive mammalian order (Kriegs et al., 2006), only Euphractus sexcinctus (Morais \& Watanabe) have these papillae; indeed, the absence of this papillae here reported for Z. pichiy, was previously stated in C. vellerosus (Estecondo et al., 2001), C. villosus (Estecondo et al., 2004), Dasypus novemcinctus (Morais et al., 1991) and other genus of Xenarthra, as Myrmecophaga, Tamandua and Bradypus (Sonntag, 1923).

The microridges observed in the different papillae, as well as in the areas between papillae, are similar to those reported in all studied armadillos (Morais \& Watanabe; Estecondo et al., 2001, 2004). As was suggested by Iwasaki for other mammals, filiform papillae and microridges may also function in armadillos as a supporting structure for food-uptake, mastication and swallowing.

Finally, the comparison of the morphology of the tongue, particularly the distribution and the structure of the lingual papillae, in Z. pichiy with that in the other species of armadillos previously studied, indicate a general similarity of features within the family Dasypodidae.

CIUCCIO, M.; ESTECONDO, S. \& CASANAVE, E. B. Estudio al microscopio electronico de barrido de la superficie dorsal de la lengua de Zaedyus pichiy (Mammalia, Xenarthra, Dasypodidae). Int. J. Morphol., 26(1):13-18, 2008.

RESUMEN: Se estudió la superficie dorsal de la lengua de Zaedyus pichiy (Desmarest, 1804), utilizando microscopía electrónica de barrido. Se describen papilas filiformes cónicas y ramificadas, fungiformes y caliciformes. No se observaron papilas foliadas. Las papilas filiformes cónicas se observan en el ápice de la lengua, en los bordes laterales y posteriormente a las papilas caliciformes. Las filiformes ramificadas representan el tipo más numeroso de papilas linguales y se encuentran distribuidas en toda la superficie dorsal de la lengua. Las papilas fungiformes se localizan entre las filiformes ramificadas y son más numerosas en el tercio anterior de la lengua. En el tercio posterior se observan dos papilas caliciformes rodeadas por un surco profundo. Las papilas fungiformes y caliciformes están relacionadas con el sentido del gusto, en su superficie se observan poros gustativos. Las papilas filiformes tienen funciones mecánica y de protección.

PALABRAS CLAVE: Mamíferos; Xenarthra; Dasypodidae; Armadillo; Lengua; Papilas linguales; SEM. 


\section{REFERENCES}

Casanave, E. B. \& Galíndez, E. J. The spleen of the armadillo: lessons of organ adaptation. Chapter 11, in Biology of the Xenarthra, Jim Loughry and S. Vizcaíno edits. Univ. of Florida press, in press. ISBN: 9780813031651.

Cuba Caparo, A. Atlas de histología del armadillo de 7 bandas Dasypus hybridus. Centro Panamericano de Zoonosis, Buenos Aires, 1979, 166 pp.

Díaz, G. B. \& Ojeda, R. A. Libro rojo de los mamíferos amenazados de la Argentina, SAREM, 2000. p. 41.

Emura, S.; Okumura, T.; Chen, H. \& Shoumura, S. Morphology of the lingual papillae in the raccoon dog and fox. Okajimas Folia Anat. Jpn., 83(3):73-6, 2006.

Emura, S.; Tamada, A.; Hayakawa, D.; Chen, H. \& Shoumura, S. B. SEM study on the dorsal lingual surface of the nutria, Myocastor coypus. Kaibogaku Zasshi., 76(2):233-8, 2001.

Estecondo, S.; Codón, S. M. \& Casanave, E. B. Histological study of the digestive tract of Dasypus hybridus (Desmarest, 1804) and Zaedyus pichiy (Desmarest, 1804) (Mammalia, Dasypodidae). Iheringia, Sér. Zool., 81:7$12,1996$.

Estecondo, S.; Codón, S. M. \& Casanave, E. B. Scanning electron microscopy study of the dorsal surface of the tongue in Chaetophractus vellerosus (Mammalia, Dasypodidae). Rev. Chil. Anat., 19: 245-52, 2001.

Estecondo, S.; Codón, S. M. \& Casanave, E. B. Scanning electron microscopic (SEM) study of the dorsal surface of the Chaetophractus villosus (Desmarest, 1804) (Mammalia, Dasypodidae) tongue. Physis, Secc., 59(136-137):23-7, 2004.

Estecondo, S.; Codón, S. M. \& Casanave, E. B. Histological study of the salivary glands in Zaedyus pichiy (Mammalia, Xenartrha). Int. J. Morphol., 23(1):19-24, 2005.

Galíndez, E. J.; Estecondo, S. \& Casanave, E. B. The spleen of Zaedyus pichiy (Mammalia, Dasypodidae). A light and electron microscopic study. Anat. Histol. Embryol., 32(4):194-9, 2003.

García Samartino, L.; Affanni, J.; Casanave, E. B.; Ferrari R. \& Iódice O. On the presence of a peculiar alpha rhythm in the olfactory tubercle of waking armadillos. Electroencephalography and Clinical Neurophysiology, 66:185-90, 1987.

Gardner, A. L. Order Cingulata. In: D. E. Wilson \& D. M. Reeder (eds.), Mammal Species of the World. $3^{\text {rd }}$ ed. Baltimore, Johns Hopkins University Press, 2005. pp. 94-9.

Iwasaki, S. Evolution of the structure and function of the vertebrate tongue. J. Anat., 201:1-13, 2002.

Jackowiak, H. Scanning electron microscopy study of the lingual papillae in the European mole (Talpa europea, L., Talpidae). Anat. Histol. Embryol., 35(3):190-5, 2006.

Jackowiak, H. \& Godinicki, S. The scanning electron microscopic study of lingual papillae in the silver fox (Vulpes vulpes fulva, Desmarest, 1820). Ann. Anat., 186:179-83, 2004.

Jackowiak, H. \& Godinicki, S. The distribution and structure of the lingual papillae on the tongue of the bank vole Clethrionomys glareolus. Folia Morphol., 64(4):32633, 2005.

Kobayashi, K.; Jackowiak, H.; Frackowiak, H.; Yoshimura, K. \& Kumakura, M. Comparative morphological study on the tongue and lingual papillae of horses (Perissodactyla) and selected ruminantia (Artiodactyla). Ital. J. Anat. Embryol., 110(2 Suppl 1):55-63, 2005.

Kriegs, J. O.; Churakov, G.; Kiefmann, M.; Jordan, U.; Brosius, J. \& Schmitz, J. Retroposed Elements as Archives for the Evolutionary History of Placental Mammals. PLoS Biol., 4(4):537-44, 2006.

Kulawik, M. \& Godynicki, S. Vallate papillae in the domestic rabbit (Oryctolagus cuniculus f. domestica). Pol. J. Vet. Sci., 10(1):47-50, 2007.

Kumar, S. \& Bate, L. Scanning electron microscopy of the tongue papillae in the pig (Sus scrofa). Micr. Res.Tech., 63:253-8, 2004.

Martinez, M.; Martinez, F.; Pinheiro, P. F.; Almeida, C. C. D.; Guida, H. L. \& Watanabe, L. Scanning electron microscopic study of the vallate papillae of the opossum (Didelphis albiventris). Rev. Chil. Anat., 16:67-73, 1998. 
CIUCCIO, M.; ESTECONDO, S. \& CASANAVE, E. B. Scanning electron microscopy study of the dorsal surface of the tongue in Zaedyus pichiy (Mammalia, Xenarthra, Dasypodidae). Int. J. Morphol., 26(1):13-18, 2008.

Martinez, M.; Martinez, F.; Pinheiro, P. F.; Almeida, C. C. D.; Segatelli, T. M. \& Watanabe, L. Scanning electron microscopic study of the tongue of chinchilla (Chinchilla laniger). Rev. Chil. Anat., 18:53-9, 2000.

Morais, J. O. \& Watanabe, I. Observaçoes morfológicas das papilas linguais do tatu peba (Euphractus sexcinctus). Estudo aos microscópios óptico e eletronico de barredura. Rev. Bras. Cien. Morfol., 5:89-97, 1988.

Morais, J. O.; Watanabe, I. \& Köning, B. Scanning electron microscopy of the lingual mucosa of the nine-banded armadillo, Dasypus novemcinctus. Ann. Anat., 176:35761, 1994.

Morais, J. O.; Watanabe, I. \& Lopes, R. A. Scanning electron microscope study of the tongue mucosa in the ninebanded armadillo, Dasypus novemcinctus. Zool. Jb. Anat., 121:267-74, 1991.

Okada, S. \& Schraufnagel, D. E. Scanning electron microscopic structure of the lingual papillae of the common opossum (Didelphis marsupialis). Microsc. Microanal., 11(4):319-32, 2005.

Parera, A. Los mamíferos de la Argentina y de la Región Austral de Sudamérica. Buenos Aires, El Ateneo, 2002. pp. 94-113.

Sonntag, C. F. The comparative anatomy of the tongue of the mammalia. IX. Edentata, Dermoptera and Insectivora. Proc. Zool. Soc. London, 515-29, 1923.

Squarcia, S. \& Casanave, E. B. Discriminación entre las subespecies de Zaedyus pichiy, Mammalia, Dasypodidae utilizando caracteres morfométricos craneanos. Physis., 57 (132-133):19-24, 1999.

Texera, W. A. Zaedyus pichiy (Edentata, Dasypodidae) nueva especie en La Provincia de Magallanes, Chile. Ans. Inst. Pat., 4:335-7, 1973.

Ünsal, S.; Aktümsek, A.; Celik, I. \& Sur, E. The number and distribution of fungiform papillae and taste buds in the tongue of young and adult Akkaraman sheep. Revue Méd. Vét., 154(11):709-14, 2003.

Watanabe, L.; Morais, J. O.; Yokoyama, R.; Inokuchi, T. \& Hamassaki, M. Three-dimensional structure of the epithelial connective tissue papillae of the armadillo Dasypus novemcinctus tongue. Rev. Chil. Anat., 10:97103, 1992.
Yoshimura, K.; Sindo, J. \& Kobayashi, K. Scanning electron microscopy study of the tongue and lingual papillae of the California sea lion (Zalophus californianus californianus). Anat. Rec., 267:146-53, 2002.

Correspondence to:

Prof. Dra. Emma B. Casanave

Universidad Nacional del Sur

Depto. de Biología, Bioquímica y Farmacia

San Juan 670

8000 Bahía Blanca

ARGENTINA

E-mail: casanave@criba.edu.ar.

Received: 12-10-2007

Accepted: 27-11-2007 